\title{
ISOLATION AND CHEMICAL CHARACTERIZATION OF BIOACTIVE ALKALOID FROM ARGYREIA SPECIOSA LINN. HAVING ACTION ON ISOLATED RAT LEYDIG CELLS
}

\author{
NIRAJ VYAS ${ }^{1 *}$, KANAN GAMIT ${ }^{1}$, MANAN RAVAL ${ }^{1}$, SAMIR PATEL ${ }^{2}$ \\ ${ }^{1}$ Department of Pharmacognosy and Phytochemistry, Ramanbhai Patel College of Pharmacy, CHARUSAT Campus, Off Nadiad - Petlad \\ Highway, Changa, 388421, Anand, Gujarat, India, ${ }^{2}$ Department of Pharmaceutical Chemistry and Analysis, Ramanbhai Patel College of \\ Pharmacy, CHARUSAT Campus, Off Nadiad - Petlad Highway, Changa, 388421, Anand, Gujarat, India. Email: nirajvyas4me@gmail.com
}

Received: 05 July 2019, Revised and Accepted: 13 August 2019

ABSTRACT

Objective: The present study was aimed to isolate and characterize bioactive constituent from alkaloid fraction, prepared from roots of Argyreia speciosa (AS) Linn.

Methods: Literature review revealed the presence of ergoline of alkaloids in roots. Alkaloidal fraction was prepared and screened for its action on testosterone biosynthesis, in vitro, using isolated rat Leydig cells. Dehydroepiandosterone was used as positive control. This bioactive fraction was subjected to open column chromatography followed by flash chromatography, to isolate constituent. One compound (A1) was isolated and its purity was ascertained using thin-layer chromatography (TLC) and high-performance liquid chromatography (HPLC) studies. A1 was characterized by IR, mass, and ${ }^{1} \mathrm{H}-\mathrm{NMR}$ studies. A1 was screened for action on testosterone synthesis in vitro. The fraction was standardized with respect to the amount of A1 present.

Results: Alkaloidal fraction $(1000 \mu \mathrm{g} / \mathrm{ml})$ incubated Leydig cells showed 22-fold increase in testosterone content as compared to untreated cells. TLC studies indicated that A1 might possess ergoline moiety in the structure. IR, mass, and ${ }^{1} \mathrm{H}-\mathrm{NMR}$ spectral studies suggested that A1 might be $\mathrm{N}$-methylergometrine. This was the first report included isolation and characterization of N-methylergometrine from AS. A1 (1000 $\mu \mathrm{g} / \mathrm{ml})$ was found to stimulate testosterone content, by 14.62-fold, in culture media of Leydig cells after incubation.

Conclusion: The results of in vitro studies confirmed that the standardized alkaloid fraction as well as A1 had ability to stimulate Leydig cells to secrete testosterone. A1 might be $\mathrm{N}$-methylergometrine and being ergometrine derivative, it might act through oxytocin receptors expressed on the Leydig cells and stimulates testosterone synthesis.

Keywords: Aphrodisiac, Spermatogenic, Argyreia speciosa, Ergoline alkaloids, Leydig cells.

(c) 2019 The Authors. Published by Innovare Academic Sciences Pvt Ltd. This is an open access article under the CC BY license (http://creativecommons. org/licenses/by/4. 0/) DOI: http://dx.doi.org/10.22159/ajpcr.2019.v12i10.34789

\section{INTRODUCTION}

Argyreia speciosa (AS) Linn. is a woody creeper plant belonging to the Convolvulaceae family. The plant is commonly known as Samudrasosha in Indian traditional medicinal system. The plant is used as Vajikarana Dravya in Ayurveda and known to possess spermatogenic properties [1]. Ayurvedic text describes the roots of the plant to be spermatogenic, aphrodisiac and increases the quality of semen [2-4]. The root powder of the plant is included in numbers of Ayurvedic and herbal preparations used to treat debilities related to male reproductive system [5].

Chemical investigations revealed the presence of ergoline type of alkaloids and flavonoids in the roots of plant. Several esters of fatty acids along with flavonoids such as scopoletin and liqueritin were isolated from the roots. Preliminary phytochemical investigation of aqueous and methanolic extracts of root revealed the presence of alkaloids, glycosides, amino acid, tannins, and flavonoids [6-12].

Previously, alcoholic extract of roots showed aphrodisiac activity in male rats with evident from stimulated mounting behavior in a dose-dependent manner [13]. Some alkaloids such as apomorphine, L-DOPA [14], and arecoline [15] showed spermatogenic and aphrodisiac activity when tested individually as well as in the form of fractions. Therefore, the present set of studies was aimed to isolate and characterize bioconstituent responsible for action on testosterone synthesis evaluated using rat Leydig cells, through bioactivity guided fractionation.

\section{MATERIALS AND METHODS}

\section{Apparatus}

Soxhlet extraction apparatus, consisting of extraction chamber, round bottom flask, and condenser, was used for the extraction of the plant material. Flash chromatographic system (Isolera-I, Biotage) was used for the separation of compounds from fraction. Rotary vacuum evaporator (Heidolph, Germany) was used to concentrate the extract while preparing alkaloid enriched fraction from roots.

\section{Reagents, solvents, and chemicals}

Analytical grade reagents, solvents, and chemicals used in the studies were purchased from LOBA Chemie, India. Media and other materials for in vitro studies were procured from Hi-Media, India; Acros Organics, India; and Sigma-Aldrich, USA.

\section{Plant materials}

The roots of AS were collected from tribal region. Roots were identified and authenticated by Taxonomist, J and J College of Science, Nadiad, and certificate of authentication was issued with voucher (Reference No.: 2011/NV/AS) submitted to Pharmacognosy Department. The roots were cleaned manually to remove adhering dirt and sand. They were cut manually and subjected to drying at room temperature under shade for 15 days and subsequently in tray dryer for 3 days at $60^{\circ} \mathrm{C}$ and then milled to 70\# using laboratory grinder. The powder was stored in an airtight container for further process of extraction.

\section{Preparation of alkaloidal fraction (ASALK)}

ASALK was prepared as per the method described by Vyas and Raval [16]. Briefly, $5 \mathrm{~kg}$ of root powder was treated with methanolic (00196, 
Loba Chemie) and $10 \%$ potassium hydroxide (05378, Loba Chemie) in with sufficient quantity. Moist powder was dried and subjected to Soxhlet extractor for extraction with $2 \mathrm{~L}$ of chloroform (00076, Loba Chemie) for $48 \mathrm{~h}$ at $60^{\circ} \mathrm{C}$. Chloroform extract was reduced to $500 \mathrm{ml}$ through concentration and recollection in rotary vacuum evaporator at $30^{\circ} \mathrm{C}$. Concentrated extract was subjected to partitioning with equal amount of aqueous sulfuric acid (10\%). Aqueous layer was collected and basified with aqueous potassium hydroxide solution $(10 \%)$ to $\mathrm{pH} \sim 9$. Basified aqueous portion was subjected to partitioning with chloroform. Pooled chloroform layers were evaporated completely to yield dry mass. Yield of alkaloid fraction was determined and found to be $0.02 \% \mathrm{w} / \mathrm{w}$. Further, thin-layer chromatography (TLC) studies were carried out for the detection of alkaloids present in the fraction.

\section{Alkaloid detection in ASALK}

ASALK was subjected to TLC studies to confirm the presence of alkaloids. Petroleum ether:chloroform:methanol:ammonia (1.0:9.5:0.5:0.07 v/v/ $\mathrm{v} / \mathrm{v}$ ) was used as an optimized mobile phase to separate alkaloids on stationary phase composed of silica gel (Silica gel G60 $\mathrm{F}_{254}$, Merck) coated TLC plates. Chamber was saturated with mobile phase for $10 \mathrm{~min}$ while run distance was set to $80 \mathrm{~mm}$ at $25 \pm 2^{\circ} \mathrm{C}$. After development, the plate was seen at $254 \mathrm{~nm}$ and $366 \mathrm{~nm}$ wavelength in UV cabinet. The plate was then derivatized with Dragendorff's reagent, dried, and scanned using Scanner IV at $520 \mathrm{~nm}$ using reflectance absorbance mode. The photograph of TLC plate and picture of chromatogram are shown in Fig. 1.

\section{In vitro studies of ASALK}

In vitro studies were performed as described previously [16,22-25]. Protocol for in vitro studies was duly approved by the Institutional Animal Ethics Committee formed as per the Committee for the Purpose of Control and Supervision of Experiments on Animals norms (Protocol number: RPCP/IAEC/2011-12/R7). Healthy male Wistar rats of weight between 250 and $350 \mathrm{~g}$ were used. Animals were received from Anand Agricultural University, Gujarat, India. All animals were housed in institutional animal house at temperature $25^{\circ} \mathrm{C} \pm 2^{\circ} \mathrm{C}$ and relative humidity of $75 \% \pm 5 \%$ in $12 \mathrm{~h}$ light/dark cycle. A basal animal diet and water were provided ad libitum.

\section{Preparation of positive control and test solutions for in vitro screening}

$10 \mathrm{mg}$ dried fraction was dissolved in dimethyl sulfoxide (DMSO) and diluted appropriately to make 10,100 , and $1000 \mu \mathrm{g} / \mathrm{ml}$ concentration. Dehydroepiandrosterone (DHEA) served as positive control for in vitro studies. $10 \mathrm{mg}$ DHEA was dissolved in DMSO appropriately to produce 10,100 , and $1000 \mu \mathrm{g} / \mathrm{ml}$ concentration. These solutions were used for in vitro studies.

Preparation of rat Leydig cells

Aseptically testes of male rats were dissected out and Leydig cells were isolated using collagenase dispersion method described previously $[16,17,22-25]$. Viability of cells was determined by trypan blue cell exclusion method while the purity of cells was checked by positive staining of $3 \beta$-hydroxysteroid dehydrogenase. Finally, Leydig cell

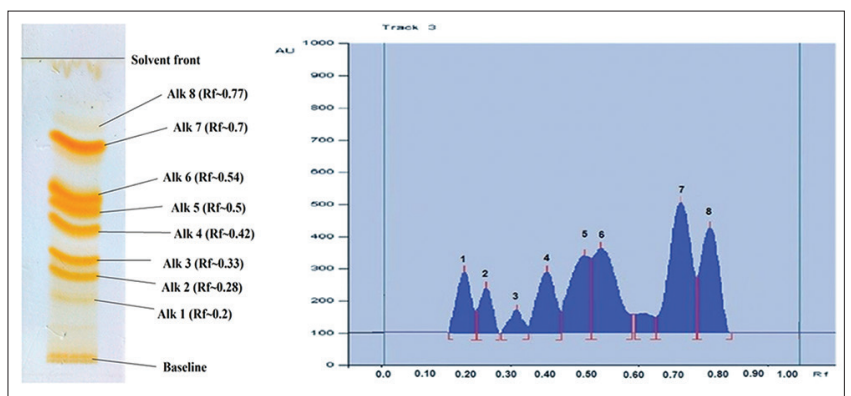

Fig. 1: (a) TLC profile of ASALK after derivatization with Dragendorff's reagent (b) Chromatogram of ASALK recorded at $450 \mathrm{~nm}$ concentration was set to $1 \times 10^{6}$ cells/ml by dilution with incubation medium.

\section{Treatment of cells with fractions and incubation}

In vitro experiment was divided into four groups: Blank: Incubation medium without cells; control: $1 \mathrm{ml}$ cells mixed with incubation medium to make final volume up to $1 \mathrm{ml}$; positive standard: $1 \mathrm{ml}$ cells mixed with $0.1 \mathrm{ml}$ of 10,100 , and $1000 \mu \mathrm{g} / \mathrm{ml}$ DHEA concentration and diluted up to $2 \mathrm{ml}$ with incubation medium; and test: $1 \mathrm{ml}$ cells mixed with $100 \mu \mathrm{l}$ of 10,100 , and $1000 \mathrm{mg} / \mathrm{ml}$ ASALK concentration and diluted up to $2 \mathrm{ml}$ using incubation medium.

All the cells were incubated at an atmosphere of $95 \% \mathrm{CO}_{2}$ using $\mathrm{CO}_{2}$ incubator at $37^{\circ} \mathrm{C}$ for $3 \mathrm{~h}$. Triplicate samples were put in the assay $(\mathrm{n}=3)$. After incubation, tubes were centrifuged at $4000 \mathrm{~g}$ for $10 \mathrm{~min}$ at $4{ }^{\circ} \mathrm{C}$ temperature. The supernatant from each tube was collected and partitioned with $1 \mathrm{ml}$ chloroform, individually. Chloroform layer was the amount of testosterone present in culture tube which was measured immediately using HPTLC method. Testosterone was separated on stationary phase composed of Silica gel $\mathrm{GF}_{254}$ aluminumcoated TLC plate with mobile phase of benzene:ethyl acetate $(1: 1 \mathrm{v} / \mathrm{v})$ with 15 min of chamber saturation time. Testosterone was detected at $240 \mathrm{~nm}$ using deuterium as a light source in Scanner IV and data were integrated using WinCATS1.4.7 software. The amount of testosterone measured is expressed as $\mathrm{mg} \%$ as shown in Fig. 2. Results of in vitro studies are expressed as Mean \pm SEM. One-way ANOVA test followed by Dunnett's test was performed to calculate the difference between the mean values of results. In all statistical tests, $p<0.05$ was considered as statistically significant. All analyses were performed using Microsoft Excel 2007.

\section{Isolation and characterization of compound from ASALK} Isolation of compounds using column chromatography

$1 \mathrm{~g}$ ASALK was dissolved in chloroform and then mixed with $5 \mathrm{~g}$ silica (60-120\#) for column chromatography. Glass column $(25 \mathrm{~mm}$ diameter, $90 \mathrm{~cm}$ long) was packed with silica $(60-120 \#, 50 \mathrm{~g})$ slurry, prepared in hexane. The mixture was evaporated to dryness using water bath. Alkaloidal fraction loaded on silica was subjected to column chromatography to isolate individual compound/s. Elution was started with $500 \mathrm{ml}$ of chloroform. Subsequently, elution was carried out by gradual increase in concentration $(0.5 \%, 1 \%, 2 \%, 5 \%, 7 \%, 9 \%$, and $10 \% \mathrm{~V} / \mathrm{V}$ ) of methanol (100 ml of each fraction). The flow rate was set to $10-15$ drops per min during elution. Each fraction was concentrated using rotary vacuum evaporator and subjected to TLC. Fractions with similar TLC profile were combined together. The fractions collected from column chromatography were subjected to flash chromatography for further separation and purification of alkaloidal compound/s.

Isolation of compounds from subfractions using flash chromatography The fractions showing similar TLC profile collected using column chromatography were subjected to flash chromatography for isolation of individual constituent. It was loaded in SNAP KP-Sil plastic cartridge contained with $50 \mathrm{~g}$ silica as stationary phase. Elution in flash chromatography was started with mobile phase of chloroform:methanol (linear gradient system) with flow rate of $10 \mathrm{ml} / \mathrm{min}$. Elutes were scanned continuously at $238 \mathrm{~nm}$ and $333 \mathrm{~nm}$ throughout the experiment. The fractions (each of $20 \mathrm{ml}$ ) were collected using fraction collector in test tubes unless a drift observed in absorbance at the set wavelengths. Each fraction was concentrated and subjected to TLC, individually. The fractions yielded single spot on TLC were mixed together and evaporated to dryness. The detailed report of flash chromatogram is shown in Fig. 3. One alkaloidal compound (A1 200 mg) was isolated from subfraction of ASALK.

Purity assessment of A1

Purity of A1 was confirmed by performing TLC studies using three different mobile phases. Plates were sprayed with Dragendorff's reagent. Sample solution (1000 ng/spot) of A1 yielded sharp, single spot in three different mobile phases. A1 was also subjected to purity 
analysis using HPLC. TLC pattern of A1 in three different mobile phases is shown in Fig. 4.

\section{Spectral studies of compound A1}

A1 was subjected to spectral studies using infrared (IR), nuclear magnetic resonance (1H-NMR), and mass spectroscopy (MS). The sample pellet consisting of $\mathrm{A} 1$ and anhydrous potassium bromide was placed in sample holder and IR spectrum was recorded in the range of $4000 \mathrm{~cm}^{-1}$ to $400 \mathrm{~cm}^{-1}$ using IR spectrophotometer (Nicolet 6700 , Thermo Scientific). IR spectrum of A1 was compared with that of IR spectrum of ergometrine as plant was reported to contain ergoline type of alkaloid. ${ }^{1} \mathrm{H}-\mathrm{NMR}\left(\mathrm{CDCl}_{3}\right)$ spectroscopy was performed on a Bruker Avance II spectrometer (500 MHz). Electrospray mass spectroscopy (ES-MS) analyses were performed using API-2000 MSMS (MDS SCIEX, Toronto, Canada) mass spectrometer. The probable structure of A1 was elucidated by comparing recorded spectroscopic data with the reported data of ergoline alkaloid (ergometrine) in the previous reports [18]

\section{In vitro studies of A1}

Isolated Leydig cells were incubated with 1, 10, 100, 500, and 1000 $\mu \mathrm{g} / \mathrm{ml}$ concentration of $\mathrm{A} 1$, prepared in DMSO. DMSO served as blank while DHEA solution in DMSO served as positive control. The experiments were performed by adopting the protocol described earlier in section 2.6.3. The results of the studies are shown in Fig. 2.

\section{RESULTS AND DISCUSSION}

\section{Detection of alkaloids}

ASALK was subjected to TLC studies. Mobile phase was optimized to separate maximum number of spots on silica layer. Postchromatographic derivatization using Dragendorff's reagent yielded eight prominent orange spots. The results are shown in Fig. 1(a) confirmed that fraction contained at least eight alkaloidal compounds. Developed TLC plate was scanned using scanner to record chromatogram. Recorded chromatogram, as shown in Fig. 1(b), may serve as identification parameter for ASALK.

\section{In vitro studies of ASALK}

Being terminal precursor in testosterone biosynthesis, DHEA was used as positive control. Amount of testosterone present in incubation media, after incubation period, was estimated using HPTLC method. The results indicated that the cells incubated with DHEA showed increased concentration of testosterone. Concentration of testosterone was increased by 2.8 -fold and 18.7 -fold, as compared to control, for $10 \mu \mathrm{g} / \mathrm{ml}$ and $100 \mu \mathrm{g} / \mathrm{ml}$ of DHEA, respectively. The results confirmed that the incubated cells were metabolically active and capable of synthesizing testosterone. Similarly, different concentrations of ASALK were incubated with isolated rat Leydig cells. The results indicated that testosterone concentration, in incubation media of cells treated with ASALK solutions, was increased by 3.7 -fold, 20.25 -fold, and 22.1-fold, in case of $10 \mu \mathrm{g} / \mathrm{ml}$, $100 \mu \mathrm{g} / \mathrm{ml}$, and $1000 \mu \mathrm{g} / \mathrm{ml}$ concentration, respectively. As shown in Fig. 2, increase in testosterone production was dose dependent as well as found statistically significant too, when the mean value for each dose level was compared with that of control.

\section{Isolation of alkaloidal compound from ASALK}

ASALK was subjected to column chromatography. Fractions were collected and monitored for the presence of alkaloidal compounds using TLC separation followed by derivatization with Dragendorff's reagent. Fractions having similar TLC separation pattern of alkaloidal compounds were mixed together and subjected to flash chromatography for isolation of individual phytoconstituent. Flash chromatography was performed on Biotage Isolera ${ }^{\mathrm{TM}}$ One flash chromatographic system using SNAP KP-Sil plastic cartridge ( $50 \mathrm{~g}$ silica gel) with mobile phase: Chloroform:methanol (linear gradient system) with flow rate of $10 \mathrm{ml} \mathrm{min}$. Elutes were scanned continuously at $238 \mathrm{~nm}$ and $333 \mathrm{~nm}$. These wavelengths were selected after scanning spots of constituents obtained on TLC plate using TLC

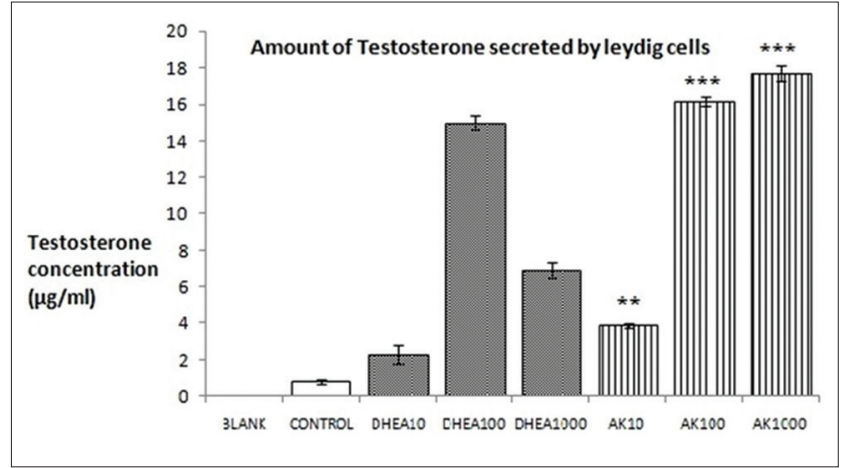

Fig. 2: Results of in vitro studies. Values are mean \pm SEM, $* \mathbf{p}<0.05, * * \mathbf{p}<0.01, * * * \mathbf{p}<0.001$ as compared to control DHEA: Dehydroepiandrosterone, AK: Alkaloidal fraction of AS

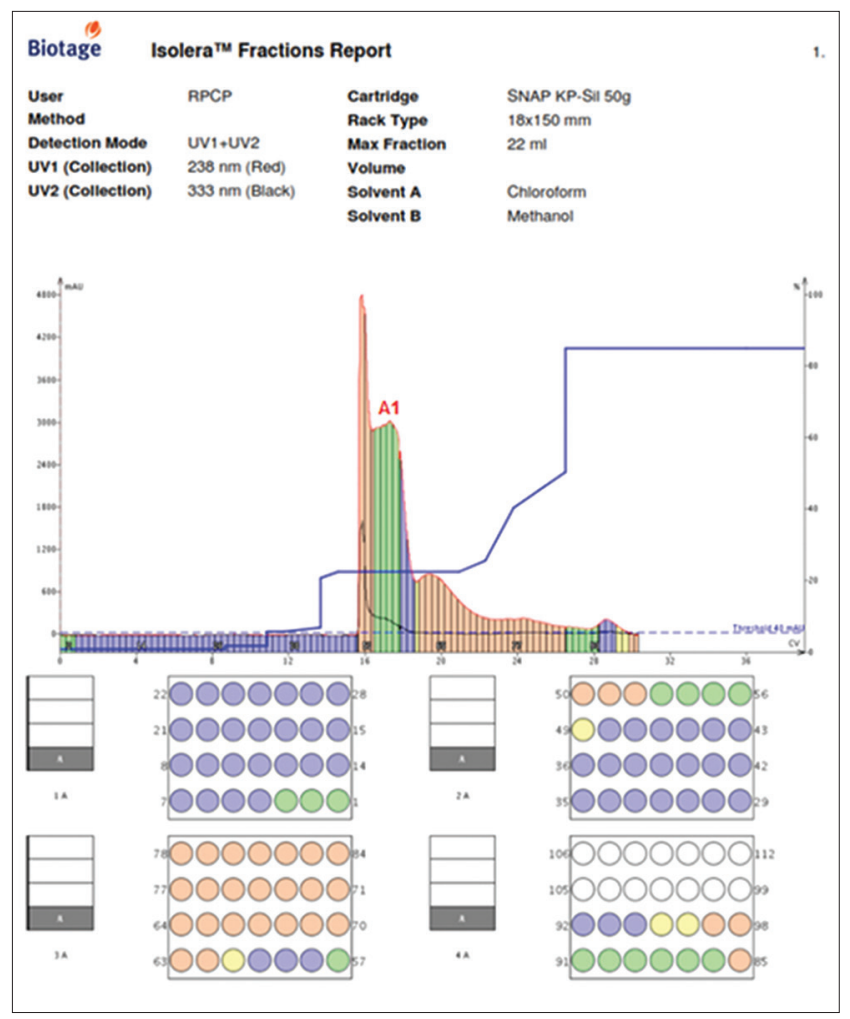

Fig. 3: Flash chromatogram for isolation of compounds from ASALK

scanner. The fractions were collected using fraction collector, operated to collect all the fractions at $238 \mathrm{~nm}$ and $333 \mathrm{~nm}$. Gradient for methanol proportion was set using trial and error. Each fraction was collected, concentrated, and subjected to TLC to detect the presence of alkaloidal compounds. Fractions with similar TLC profile were combined together. The fractions containing single spot on TLC were mixed together and evaporated to dryness. The detailed report of flash chromatogram is shown in Fig. 3. One compound (A1 200 mg) was isolated from bioactive alkaloidal fraction prepared from roots of AS.

\section{Purity assessment of isolated compound}

Purity of isolated compound (A1) was confirmed by performing TLC studies using three different mobile phases. It was revealed from literature review that AS contained ergoline type alkaloids. A1 when subjected to react with Van Urk's reagent, yielded violet color. It was positive test for the presence of ergoline alkaloids. Hence, plates after development were sprayed individually with Dragendorff's reagent as well as Van Urk's reagent. Results showed that A1 yielded sharp 
single spot in all three different mobile phase systems at different $\mathrm{R}_{\mathrm{f}}$ values. There were no other spots observed on TLC plates. Results of purity assessment performed using TLC studies are shown in Fig. 4. Purity of A1 was also ascertained using HPLC studies. Compound was subjected to reverse-phase HPLC using acetonitrile:phosphate buffer $\mathrm{pH}$ $\sim 2.5(15: 85 \mathrm{v} / \mathrm{v})$ as mobile phase on $\mathrm{C}_{18}$ column $(250 \times 4.6 \mathrm{~mm}, 5 \mu \mathrm{m})$ at temperature of $25 \pm 2{ }^{\circ} \mathrm{C}$. Flow rate was set to $1 \mathrm{ml}$ per min and scanning was performed at $313 \mathrm{~nm}$. Thus, by TLC and HPLC studies, it was confirmed that the compound A1 was pure and devoid of any impurities.

\section{Spectral characterization of isolated compound [19]}

The structure of isolated and purified compound was elucidated using IR, ${ }^{1} \mathrm{H}-\mathrm{NMR}$, and MS spectral studies.

IR (KBr disc): 1351.57 (C-N str), 1584.39, 1611.79 (CO-NH str), 2114.43, 3416.96 (Aromatic -NH str), $3731.12 \mathrm{~cm}^{-1}$.

IR spectrum showed the presence of $\mathrm{C}-\mathrm{N}$ stretch for $\mathrm{N}-\mathrm{CH}_{3}$ group $\left(1351.57 \mathrm{~cm}^{-1}\right)$, indicating probable presence of $\mathrm{N}$-methyl group in the structure of A1.

${ }^{1} \mathrm{H}-\mathrm{NMR}\left(500 \mathrm{MHz}, \mathrm{CDCl}_{3}\right) \delta$ ppm: 0.9 (t, - $\mathrm{CH}-\mathrm{CH}_{2}-$ ); 1.286 (s, -CONH-); 1.9 - $2.2\left(\mathrm{~m},-\mathrm{CH}_{2}-\right) ; 3.6\left(\mathrm{~s}, \mathrm{~N}-\mathrm{CH}_{3}\right) ; 3.31\left(\mathrm{~d},-\mathrm{CH}_{2}-\mathrm{OH}\right) ; 3.4(\mathrm{~s},-\mathrm{OH}) ; 2.27$ $\left(\mathrm{s},-\mathrm{N}-\mathrm{CH}_{3}\right) ; 4.7-4.8\left(\mathrm{t},-\mathrm{CH}-\mathrm{CH}_{2}\right) ; 6.25\left(\mathrm{~s},-\mathrm{CH}_{2}-\right.$ ring); $7.08(\mathrm{~s}, \mathrm{~N}-\mathrm{CH}=\mathrm{C})$; $7.14(\mathrm{t}, \mathrm{CH}=\mathrm{CH}=\mathrm{CH}) ; 7.2(\mathrm{~d}, \mathrm{CH}=\mathrm{CH}) ; 7.3(\mathrm{~d}, \mathrm{CH}=\mathrm{CH})$.

NMR spectrum showed all characteristic $\delta$ values for peaks as reported for ergoline ring. Recorded NMR spectrum showed chemical shift at 3.6, corresponding to three hydrogens of $\mathrm{N}-\mathrm{CH}_{3}$ group in pyrrole ring while chemical shift at 2.2 corresponding to three hydrogens of $\mathrm{N}-\mathrm{CH}_{3}$ group might be attributed to tetrahydropyridine ring (Fig. 5). We have observed only one singlet corresponding to three hydrogens of $\mathrm{N}-\mathrm{CH}_{3}$ group at chemical shift 2.2 in reported ${ }^{1} \mathrm{H}-\mathrm{NMR}$ of ergometrine. This suggested the presence of $\mathrm{N}$-methyl substituted ergometrine.

ESI-MS m/z [M+H]+340.1;calcd. 339.4314, $\mathrm{C}_{20} \mathrm{H}_{25} \mathrm{~N}_{3} \mathrm{O} 2 ; \mathrm{m} / \mathrm{z} 325.0$ $\left[\mathrm{M}-\mathrm{CH}_{3}\right]^{+}$

Molecular weight of ergometrine is $325.4 \mathrm{~g} / \mathrm{mol}$ while mass spectrum of A1 showed base peak at $\mathrm{m} / \mathrm{z} 340.1\left([\mathrm{M}+\mathrm{H}]^{+} \sim 340.1\right)$. A peak was obtained at $\mathrm{m} / \mathrm{z} 325.0$ too. This suggested removal of methyl group from $\mathrm{A} 1$ and formation of ergometrine molecular ion.

Considering the results of comparative spectral studies, structure of A1 was predicted as N-methylergometrine, as shown in Fig. 6.

\section{In vitro studies of $\mathrm{A} 1$}

Previously, ergoline alkaloids were found capable of reducing conversion of testosterone and DHT into less active metabolite in vivo [20]. However, when tested in vitro using isolated Leydig cell in another independent study, oxytocin was found to stimulate basal testosterone production by Leydig cells, without interacting LH-dependent testosterone production. It was reported that oxytocin receptors are expressed on Leydig cells and oxytocin interacts with Leydig cells through these receptors [21]. As A1 was ergometrine derivative, it was assumed that $\mathrm{A} 1$ might interact with oxytocin receptors and stimulated testosterone synthesis. The studies, thus, suggested that ergoline alkaloids from ASALK might act directly on Leydig cells in testis and increased testosterone concentration. Testosterone plays an important role in initiation and maintenance of spermatogenesis process. Thus, inflated testosterone concentration due to the effect of alkaloids on Leydig cells might be attributed to spermatogenic potential of AS.

\section{CONCLUSION}

A1 was isolated from ASALK through bioactivity guided fraction using column chromatography and flash chromatography. Spectral studies revealed $\mathrm{A} 1$ to be $\mathrm{N}$-methylergometrine. A1 and ASALK stimulated testosterone concentration in culture media of the cells, in a dosedependent manner. It was further proposed that, being ergometrine derivative, A1 might interact with oxytocin receptors and stimulated testosterone biosynthesis in Leydig cells.

\section{ACKNOWLEDGMENT}

Authors are thankful to Gujarat Council on Science and Technology, Gujarat, India, for their financial support for the work.

\section{AUTHORS' CONTRIBUTIONS}

Niraj Vyas - Preparation of extracts, in vitro and in vivo activity.

\begin{tabular}{|l|l|}
\hline Mobile phase: & Mobile phase: \\
Chloroform:methanol:ac & Chloroform:methanol:acetone \\
etone $(6: 4: 4 \mathrm{v} / \mathrm{v} / \mathrm{v})$ & $(6: 4: 4 \mathrm{v} / \mathrm{v} / \mathrm{v})$ \\
$\left(\mathrm{R}_{\mathrm{f}}=0.53\right)$ & $\left(\mathrm{R}_{\mathrm{f}}=0.53\right)$ \\
Derivatized with & Derivatized with Van Urk \\
Dragendorff's reagent & reagent \\
& \\
\hline & \\
\hline Mobile phase: & Mobile phase: \\
Toluene:ethyl & Toluene:ethyl acetate:methanol \\
acetate:methanol $(6: 2: 0.4$ & $(8: 3: 0.7 \mathrm{v} / \mathrm{v} / \mathrm{v})$ \\
v/v/v/v) & $\left(\mathrm{R}_{\mathrm{f}}=0.61\right)$ \\
(Rf $=0.40)$ & Derivatized with Dragendorff's \\
Derivatized with & reagent \\
Dragendorff's reagent & \\
\hline
\end{tabular}

Fig. 4: Purity assessment of isolated compound by TLC 
<smiles></smiles>

Fig. 5: ${ }^{1} \mathrm{H}$-NMR shifts of hydrogens in $\mathrm{N}-\mathrm{CH}_{3}$ groups in $\mathrm{A1}$<smiles></smiles>

Fig. 6: Probable structure of A1 (N-methylergometrine) (Calculated mol wt. 339.4314 g/mol)

MananRaval - Isolation of alkaloids by chromatography.

Samir Patel - Spectral studies of isolated compounds.

\section{CONFLICTS OF INTEREST}

The authors declare that they have no conflicts of interest.

\section{REFERENCES}

1. Kapoor LD. Ayurvedic Medicinal Plants. New Delhi: CRC Press; 2000.

2. Nadkarni KM. Indian Materia Medica with Ayurvedic, Unani-Tibbi, Siddha, Allopathic, Homeopathic, Naturopathic and Home Remedies. Mumbai: Popular Prakashan; 1996.

3. Sastri BN. The Wealth of India Raw Material. New Delhi: Council of
Scientific and Industrial Research; 2005.

4. Kirtikar R, Basu BD. Indian Medicinal Plants. $2^{\text {nd }}$ ed., Vol. 2. New Delhi: Periodical Express Book Agency; 1991.

5. Anonymous. Ayurvedic formulary of India. $2^{\text {nd }}$ ed. Vol. 1 . New Delhi: Government of India; 1978.

6. Khan MS, Kamil SM, Ilyas M. Phytochemical investigation on the leaves of Argyreia speciosa. J Ind Chem Soc 1992;69:195-205.

7. Ahmad M, Jain N, Khan MS, Ilyas M. Two new flavone glycosides from the leaves of Argyreia speciosa Convolvulaceae. J Chem Res Synopses 1993;7:61-8.

8. Atar M, Wasimuzzama K, Tausif S, Rukhsana A. Pharmacognostic and preliminary phytochemical investigation of Argyreia nervosa roots (Convolvulaceae). Res J Pharmacogn Phytochem 2010;2:126-9.

9. Rani A, Shukla YN. Disubstitutedtetrahydrofuran and an ester from Argyreia speciosa. Ind J Chem 1997;36:299-300.

10. Shrivastava A, Shukla YN. Aryl esters and a coumarin from Argyreia speciosa. Ind J Chem 1998;37:192-4.

11. Kelkar GM, Phalnikar NL, Bhide BV. Fatty oil from the seeds of Argyreia speciosa sweet (Convolvulaceae). J Ind Chem Soc 1947;24:83-6.

12. Agarwal SK, Rastogi RP. Ergometrine and other constituents of Argyreia speciosa sweet. Ind J Pharmacol 1974;36:118-9.

13. Subramoniam A, Madhavachandran V, Ravi K, Anuja VS. Aphrodisiac property of the elephant creeper Argyreia nervosa. J Endocrinol Reprod 2007;11:82-5.

14. Tagliamonte A, Fratta A, Gessa GL. Aphrodisiac effect of 1-DOPA and apomorphine in male sexually sluggish rats. Experientia 1974;30:381-2.

15. Wang SW, Hwang GS, Chen TJ, Wang PS. Effects of arecoline on testosterone release in rats. Am J Physiol Endocrinol Metab 2008;295:E497-504

16. Vyas NY, Raval MA. Aphrodisiac and spermatogenic potential of alkaloidal fraction of Hygrophila spinosa T. Ander in rats. J Ethnopharmacol 2016;194:947-53.

17. Sharma RS, Pal PC, Rajalakshmi M. Isolation and culture of leydig cells from adult rats. Indian J Clin Biochem 2006;21:27-33.

18. Florey K. Analytical Profiles of Drug Substances. Vol. 11. New York: Elsevier; 1982

19. Silverstein RM, Webster FX, Kiemle DJ. Spectrometric Identification of Organic Compounds. $7^{\text {th }}$ ed. New York: John Wiley and Sons; 2005.

20. Bhusari S, Hearne LB, Spiers DE, Lamberson WR, Antoniou E. Effect of fescue toxicosis on hepatic gene expression in mice. J Anim Sci 2006;84:1600-12.

21. Frayne J, Nicholson HD. Effect of oxytocin on testosterone production by isolated rat leydig cells is mediated via a specific oxytocin receptor. Biol Reprod 1995;52:1268-73.

22. Jayusman, PA, Mohamed IN, Thu HE, Shuid AN. Effect of Eurycoma longifolia on sexual behavior in sexually dysfunctional male: A systematic review. Int J Pharm Pharm Sci 2017;9:46-52.

23. Mensah KB, Benneh C, Boakye-Gyasi E. Ethanol root extract of the African aphrodisiac, Mondia whitei (Periplocaceae), possesses estrogenic activity. Int J Pharm Pharm Sci 2015;7:284-7.

24. Vyas N, Gamit K, Raval M. Male infertility: A major problem worldwide and its management in Ayurveda. Pharm Sci Monit 2018;9:446-69.

25. Vyas N, Raval M. Effect of unsaponifiable fraction of seeds of Hygrophila spinosa $\mathrm{T}$. Ander on testosterone production of rat leydig cells in vitro. Asian J Pharm Clin Res 2016;9:184-6. 